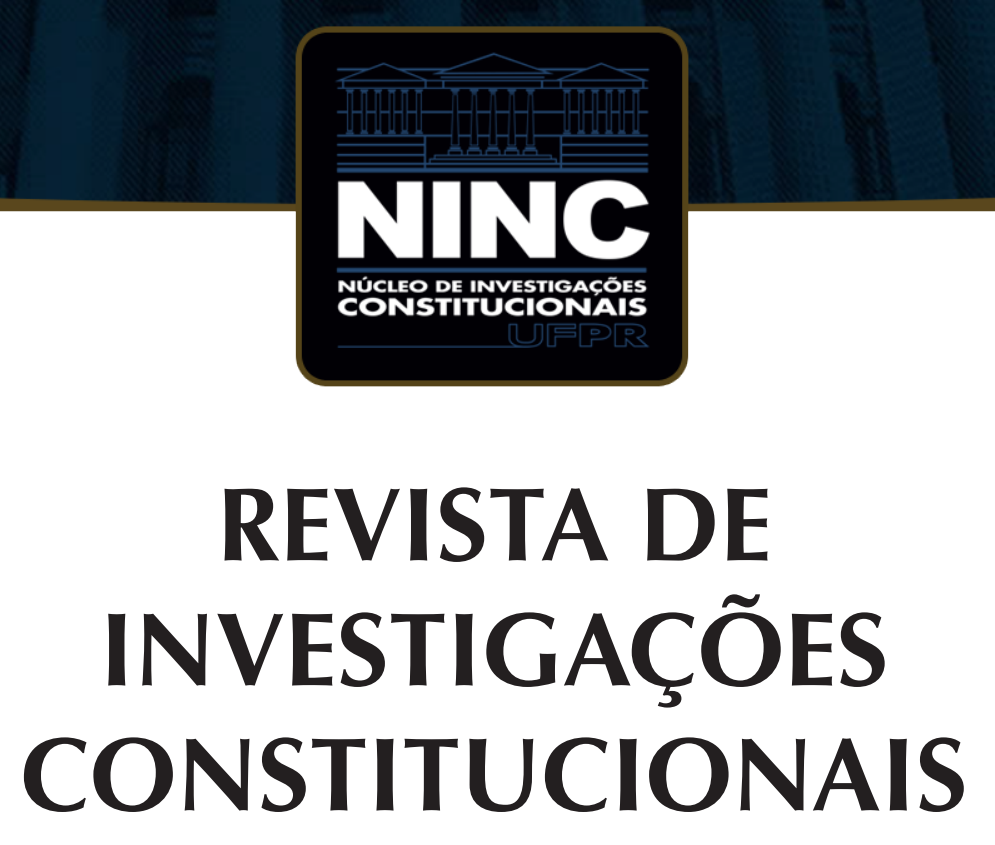

JOURNAL OF CONSTITUTIONAL RESEARCH

vol. 6 | n. 1 | janeiro/abril 2019 | ISSN 2359-5639 | Periodicidade quadrimestral Curitiba | Núcleo de Investigações Constitucionais da UFPR | www.ninc.com.br 


\section{La iniciativa legislativa popular en América Latina - Un análisis comparado en clave axiológico-procedimental"}

\section{The popular legislative initiative in Latin America - A comparative analyze in axiological and procedure perspective}

(TEODORO) YAN GUZMAN HERNÁNDEZ ${ }^{1,}$,**

${ }^{1}$ Universidad de La Habana (Cuba) yan@lex.uh.cu

https://orcid.org/0000-0002-7470-7100

Recebido/Received: 17.04.2018 / April 17 $7^{\text {th }}, 2018$

Aprovado/Approved: 29.04.2019 / April 29 th', 2019

\section{Resumen}

La Iniciativa legislativa popular (ILP) es una institución que ha ganado terreno en los últimos 30 años en América Latina. El análisis de esta institución se comparte entre el Derecho constitucional y la Teoría política, pero las exigencias de esta última, sobre la base de concepciones minimalistas de la democracia directa, han desvirtuado de cierta manera, su esencia normativo-conceptual. En e siguiente trabajo se analiza la ILP desde una perspectiva procedimental, teniendo en cuenta su regulación en la Constitución y en las leyes de desarrollo en 16 ordenamientos de América Latina. Como resultado de este análisis, se deducen principios que informan su procedimiento y que optimizan las normas que la regulan, as como una tipología menos radical y más consecuente con la incidencia del principio democrático en esta institución.

Palabras-claves: democracia directa; participación; iniciativa legislativa popular; ley; procedimiento.
Abstract

The popular legislative initiative (PLI) is an institution that has gained ground in the last 30 years in Latin America. The analysis of this institution has been shared between constitutional law and political theory, but the demands of the latter, based on minimalist conceptions of direct democra$c y$, have distorted, in a certain way, its normative-conceptual essence. In the following work, it analyzes the popular legislative initiative from a procedural perspective, taking into account its regulation in the Constitution and in the development laws in 16 Latin American legal systems. As a result of this analysis, principles are deduced that inform its procedure and that optimize the norms that regulate it, as well as a less radical typology and more consistent with the incidence of the democratic principle in this institution.

Keywords: direct democracy; participation; popular legislative initiative; law; procedure.

Como citar esse artigo/How to cite this article: HERNÁNDEZ, (Teodoro) Yan Guzman. La iniciativa legislativa popular en América Latina - Un análisis comparado en clave axiológico-procedimental. Revista de Investigações Constitucionais, Curitiba, vol. 6 , n. 1, p. 35-59, jan./abr. 2019. DOI: 10.5380/rinc.v6i1.58984.

"Se agradece la colaboración de Yanina Welp, Orestes Suárez Antón y Francisco Soto Barrientos, quienes solícitamente intercambiaron información y contribuyeron a los resultados de este estudio.

"* Profesor Titular de Derecho Constitucional y Teoría del Derecho de la Facultad de Derecho de la Universidad de La Habana (La Habana, Cuba). Doctor en Ciencias Jurídicas por la Universidad de La Habana (La Habana, Cuba) (2008). Miembro de la Sección cubana de la Sociedad Iberoamericana de Derecho Constitucional. E-mail: yan@lex.uh.cu. 


\section{SUMARIO:}

1. Introducción; 2. El marco teórico general: el principio democrático, la democratización y sus efectos en las instituciones constitucionales; 3. La iniciativa legislativa popular: orígenes, definiciones y criterios para su clasificación; 3.1. Criterios para su clasificación; 4. El examen procedimental de la iniciativa legislativa popular; 5. Situación actual de la regulación de la iniciativa legislativa popular en América Latina. Propuesta para una tipología; 6 . Algunos principios deducibles de la regulación de la iniciativa legislativa popular; 7 . Referencias.

\section{INTRODUCCIÓN}

A partir de la última década del siglo XX y las dos primeras del corriente, la ILP (ILP) ha experimentado un notable auge en su regulación constitucional y desarrollo normativo en América Latina, aun cuando temporalmente, una y otro no han venido de la mano'. Si bien la institución no ha gozado de la estima del referendo ${ }^{2}$, no ha dejado de ser analizada por el Derecho constitucional y la Teoría política.

En América latina, la ILP entendida como el derecho de una fracción del cuerpo electoral a intervenir en el procedimiento legislativo con la finalidad que se adopte una decisión política en forma de ley, presenta una configuración normativa diversa. Esta realidad ha influido no solo en su definición y tipología, sino también en una toma de postura acerca de si algunas de sus configuraciones legales, deben ser consideradas como tal en puridad de términos, al sostenerse la existencia de la iniciativa de agenda. Esto último ha sido asumido principalmente por la Teoría política, de la cual algunos de sus exponentes han terminado desvirtuando la institución, por las exigencias que esta disciplina le ha impuesto respecto a la democracia directa.

El análisis que se presenta se limita a la ILP productora de ley en sentido formal y a la de reforma constitucional, excluye a la iniciativa popular de otros actos normativos ${ }^{3}$ y a la de normas de menor jerarquía ${ }^{4}$, la cual ganó terreno constitucional en Latinoamérica, antes del reconocimiento de la iniciativa popular de ley ${ }^{5}$. En este trabajo no

\footnotetext{
'En el anexo de este trabajo se ha identificado el año correspondiente a la primera inclusión de la ILP productora de ley formal o de la iniciativa de reforma o enmienda constitucional según sea el caso, en las constituciones latinoamericanas, y el año en que se han reglado sus requisitos en la norma de menor jerarquía.

${ }^{2}$ El referéndum "es la más importante manifestación de gobierno directo". HAURIOU, Maurice. Principio de Derecho público y constitucional. Madrid: Editorial Reus, 1927, p. 500. Pérez Royo sostuvo que "la iniciativa popular tiene mucho menos importancia que el referéndum desde todos los puntos de vista. Realmente cuando se plantea el problema de la democracia directa y la representativa es en el referéndum en lo que se piensa de manera inmediata y exclusiva." PÉREZ ROYO, Javier. Curso de Derecho constitucional. 4. ed. Madrid: Marcial Pons, 1997, p. 380.

${ }^{3}$ Por ejemplo, la iniciativa de acuerdos internos de la Asamblea Nacional en Venezuela (art. 156, Reglamento Interior y de Debates de la Asamblea Nacional), o de ratificación de tratados internacionales en Ecuador (art. 420 , Const.).

${ }^{4}$ Véase nota al pie no 33.

${ }^{5}$ En Uruguay, paradigma en el área de este tipo de instituciones, se previó tempranamente para asuntos de la localidad en el artículo 141 de la Carta Magna de 1919; el artículo 266 de la Constitución de 1934 se hizo eco
} 
se hace referencia a las prácticas o experiencias de la ILP en América Latina, sobre lo cual existen resultados recientes que ofrecen datos actualizados ${ }^{6}$. Tampoco se hace un aparte para significar la trascendencia de las instituciones de democracia directa, y por ende de la ILP, para los sistemas políticos, en el contexto latinoamericano.

La ILP es una institución democrática, expresión del principio de soberanía popular, que posibilita a los ciudadanos participar más o menos directamente, en la formación del estatuto legal del Estado, su definición puede partir de su condición de derecho ciudadano ${ }^{7}$ o relacionada con el procedimiento legislativo ${ }^{8}$.

El siguiente trabajo asume la definición amplia de la ILP que se consignó al inicio, o sea, incluye lo que la Teoría política ha venido identificando como iniciativa de agenda; y se propone examinar el estatuto legal de la institución que integra a las constituciones, las leyes de desarrollo y los reglamentos parlamentarios, en 16 ordenamientos de América Latina, para presentar una panorámica general de los principales aspectos que se regulan de este instituto democrático en el área y deducir algunos principios que informan su procedimiento y pueden constituir referente para su regulación.

En primer orden se conjugará el análisis de esta institución democrática en un orden normativo, sobre la base de las definiciones de Kelsen, Hauriou, Jellinek con las valoraciones de orden político-axiológico que apreció Carl Schmitt en la participación democrática en la actividad legislativa. En segundo orden, el examen de la ILP será desde una perspectiva procedimental, o sea, teniendo en cuenta que la misma puede ser parte del procedimiento legislativo. Esto último permitirá una mejor disección de los requisitos o actos jurídicos relevantes de la institución y marcará una diferencia respecto a trabajos precedentes que la han analizado comparativamente en el área.

Además, con este trabajo se obtiene una tipología de la ILP, diferente a la postura dicotómica de algunos exponentes de la Teoría política, que defienden su existencia solo cuando media consulta, para que el cuerpo electoral decida adoptar la propuesta de ley o reforma constitucional hecha por una fracción de la ciudadanía, y de una

de la regulación anterior, democratizando aún más ese mecanismo.

${ }^{6}$ Se está haciendo referencia principalmente, a los trabajos de SOTO BARRIENTOS, Francisco. Mecanismos de participación ciudadana en el proceso legislativo. Los desafíos de su recepción en Chile. Oñati Socio-legal Series [online], Oñati, vol. 7, n. 5, p. 1-16. 2017. Disponible en <http://ssrn.com/abstract=3062784>. Acceso el 08.10.2017, y de SUÁREZ ANTÓN, Orestes; WELP, Yanina. ¿Cambio o cumbia? Análisis de la iniciativa de agenda en América Latina. Revista Boliviana de Ciencias Políticas, [s.l.], vol. 1, n. 1, p. 79-107. 2017.

${ }^{7}$ HEVIA DE LA JARA, Felipe. La iniciativa legislativa popular en América Latina. Revista Convergencia, México, vol. 17, n. 52, p. 155-185, ene./abr. 2010; SOTO BARRIENTOS, Francisco. Mecanismos de participación ciudadana en el proceso legislativo. Los desafíos de su recepción en Chile. Oñati Socio-legal Series [online], Oñati, vol. 7, n. 5, p. 1-16. 2017. Disponible en <http://ssrn.com/abstract=3062784>. Acceso el 08.10.2017; GARCÍA PELAYO, Manuel. Derecho constitucional comparado. Madrid: Alianza Editorial, 1984, p. 183.

${ }^{8}$ CONCHA CANTÚ, Hugo Alejandro. La iniciativa legislativa popular. En: Sem organizador. Cuadernos Constitucionales México-Centroamérica: 19. La reforma constitucional en México y Argentina. México: Instituto de Investigaciones Jurídicas, 1996, p. 15. Disponible en: <https://archivos.juridicas.unam.mx/www/bjv/ libros/1/191/4.pdf>. Acceso el 12.02.2017. 
iniciativa de agenda cuando la decisión final sobre la propuesta queda en manos del órgano legislativo.

\section{EL MARCO TEÓRICO GENERAL: EL PRINCIPIO DEMOCRÁTICO, LA DEMOCRATIZACIÓN Y SUS EFECTOS EN LAS INSTITUCIONES CONSTITUCIONALES}

En la actualidad la supuesta contradicción entre representación y democracia ha sido superada, algunas instituciones de democracia directa, aun cuando son entendidas como realización paradigmática de la democracia en su prístino sentido, significan un complemento necesario del régimen representativo y no una contraposición al mismo. No obstante, determinados autores prefieren distinguir las instituciones de democracia semidirecta de las de democracia directa, porque en las primeras median las instancias de poder ${ }^{9}$, de ahí que reduzcan el ámbito de las primeras a la landsgemeinde suiza, al referendo preceptivo y al instado por los ciudadanos con carácter vinculante, así como a la ILP ${ }^{10}$ siempre que esta última sea "el derecho de una fracción del cuerpo electoral a exigir la consulta popular sobre una determinada acción legislativa"11.

Tanto de la democracia en su condición de valor, como de la representación política, se derivan principios jurídico-políticos. La propia génesis del concepto «democracia», resultante de la extrapolación de una particular dinámica participativa sobre la base de una libertad e igualdad "premodernas", a la postre, juzgadas por la modernidad política ${ }^{12}$, ha traído consigo la pertinencia de hablar de "aspiración democrática» ${ }^{13}$, lo que fundamenta en parte la esencia deontológica del principio democrático. Por otro lado, la inmanencia de la representación política, asumida como una técnica de gobierno, en manos de un grupo y ante la imposibilidad del todo soberano para decidir

\footnotetext{
9 “La teoría constitucional refiere a esta variante como la forma semidirecta o semirrepresentativa. El electorado participa mediante referéndum en la función legislativa, particularmente cuando es preceptivo para las enmiendas constitucionales, en algunos ordenamientos incluso, puede promover una decisión política que posteriormente será aprobada por el gobierno y el parlamento". LOEWENSTEIN, Karl. Political power and the governmental process. 2. ed. Chicago \& London: The University of Chicago Press, 1967, p. 79. Traducción del autor.

${ }^{10}$ Posición que por ejemplo asume GARCÍA PELAYO, Manuel. Derecho constitucional comparado. Madrid: Alianza Editorial, 1984, p. 183.

${ }^{11}$ GARCÍA PELAYO, Manuel. Derecho constitucional comparado. Madrid: Alianza Editorial, 1984, p. 183.

${ }^{12}$ Esto quedó expuesto por Benjamin Constant en CONSTANT, Benjamin. De la libertad de los antiguos comparada con la de los modernos. Disponible en: <https://omegalfa.es/downloadfile.php?file=libros/discurso-de-la-libertad-de-los-antiguos-comparada-con-la-de-los-modernos.pdf>.

${ }^{13}$ Sartori advierte que "Para evitar un mal comienzo debemos, por tanto, conservar in mente que: a) el ideal democrático no define la realidad democrática y, viceversa, una democracia real no es ni puede ser una democracia ideal; b) que la democracia resulta de, y es conformada por, las interacciones entre sus ideales y su realidad, el empuje del deber y la resistencia del es. SARTORI, Giovanni. Teoría de la democracia. El debate contemporáneo. Madrid: Alianza Editorial, 1995, p. 27.
} 
políticamente por sí mismo como ente subjetivo estatalmente organizado, denotaría la naturaleza ontológica del principio de representación.

La evolución del constitucionalismo en el marco de los regímenes políticos, ha puesto en evidencia que ambos principios han interactuado con diferente fuerza, el principio democrático ha venido informando el diseño de las instituciones que conforman estos regímenes, incluso de las que nacieron asociadas a la representación política, como por ejemplo, el propio acto de creación de las leyes que nació como un típico acto de representación política. Esto ha aportado la «democratización» como un concepto dinámico, derivado de la democracia, que sirve para entenderla como un proceso y de la cual se deriva su lógica evolutiva. La naturaleza deontológica y ontológica del principio democrático y de representación, respectivamente, son claves para entender que ambos principios pueden ser colocados en virtud de sus esencias, en ejes perpendiculares que deberán encerrar un área regulada por la Constitución, donde se trataría de resolver una de las tensiones sempiternas de toda realidad constitucional, la que se produce entre poder y libertad.

La democratización asumida como la derivación dinamizadora y progresiva del concepto «democracia» ha impactado en la valoración que se hace de la democracia directa y sus instituciones. La tesis de Lissidini acerca de que es posible constatar concepciones "minimalistas" de las instituciones de democracia directa que la reducen al referendo; "extensionistas" que integran a todos los mecanismos de participación ciudadana en los que media el voto (con la excepción de las elecciones), y que pueden llegar a abarcar la ILP, aun cuando quede reducida a la propuesta de ley al legislativo; y, por último, "maximalistas" que abarcan los presupuestos participativos, así como los instrumentos de control ciudadanos, por ejemplo, la defensoría del pueblo y la auditoría ciudadana ${ }^{14}$, nos pone al corriente no solo de la diversidad de criterios acerca de qué entender por democracia directa ${ }^{15}$ y cuáles instituciones se inscriben dentro de ella, sino también de que el principio democrático es capaz de optimizar las instituciones participativas de forma diversa y en diferente grado, lo que puede manifestarse en una institución en particular, como se verá en el caso de la ILP.

Si se asume que la iniciativa legislativa, en su forma "simple", como "el derecho de presentar a la Cámara una proposición encaminada a obtener la votación de un

\footnotetext{
${ }^{14}$ LISSIDINI, Alicia. Democracia directa en América Latina. Buenos Aires: C2D, International IDEA, Escuela de Política y Gobierno UNSAM y Prometeo Libros, 2008, p. 13-14.

${ }^{15}$ Otterman trae a colación las definiciones de Sanford Lakoff en Democracy: History, Theory, Practice, de la Encyclopedia of Democratic, de David Altman en "Direct democracy Worldwilde" y la de A Dictionary of Modern Politics, en las que la participación directa de los ciudadanos y la decisión en las urnas son elementos constitutivos de la democracia directa. OTTERMAN, Steven. The European Citizens' Initiative: a Tool of Direct Democracy? En: ALTUNA, Asier; SUÁREZ, Mariluz (Org). New Voices in Euroculture. Groningen: Euroculture consortium. Disponible en: <www.rug.nl/research/portal/files/29253730/european.pdf>. Acceso el 13.06.2017.
} 
proyecto o un acuerdo"16 (popular si ese derecho lo tiene la ciudadanía), permitirá disponer, momentáneamente, de otras valoraciones acerca de si la ILP puede/debe o no ser considerada una institución de democracia directa, pues ello dependerá del concepto que se asuma de esta última y de las formas de configurarse la participación popular en el procedimiento legislativo que resulte de la iniciativa popular.

En un sentido normativo-procedimental, la definición que ofrece Concha Cantú es funcional, al sostener que la ILP consiste en la transmisión de la potestad de iniciar, precisamente, el procedimiento de formación de la ley formal a una fracción del pueblo mismo [...] así como al hecho de que también se utiliza para referirse al procedimiento de revisión constitucional. ${ }^{17}$

Como se verá en el examen de la ILP en América Latina, algunas manifestaciones de esta institución pudieran quedar encuadradas dentro de las instituciones de democracia directa, mientras que otras no, pero en la evolución democrática de la institución queda en evidencia que la participación ciudadana, expresión incuestionable del principio democrático, se ha venido manifestando con diferente fuerza y grado en el iter procedimental que puede describir la misma.

\section{LA INICIATIVA LEGISLATIVA POPULAR: ORÍGENES, DEFINICIO- NES Y CRITERIOS PARA SU CLASIFICACIÓN}

La ILP tuvo sus orígenes en al antiguo derecho de instancia o petición, asociado a las monarquías más absolutas y bajo las tiranías asiáticas ${ }^{18}$, alcanzó tanto un uso privado como público, en dependencia de la naturaleza de lo solicitado. Maurice Haoriou al tratarlo en su obra Principios de Derecho Público y Constitucional, acotó que el derecho de petición “jugó un gran papel político bajo la Revolución, cuando los mismos peticionarios exponían su factum a las Asambleas", y pervivió mientras la prensa no conquistó su papel vital en la formación de la opinión pública ${ }^{19}$.

La iniciativa popular con incidencia en la legislación, se reguló por primera vez en la Constitución suiza de 1848, al margen de los atisbos que se pudieran encontrar en el artículo 6 de la Declaración de los Derechos del Hombre y del Ciudadano o en el Proyecto Girondino de $1793^{20}$. En la Carta Magna suiza se circunscribió a la reforma de

\footnotetext{
${ }^{16}$ Definición de Duguit basada en la Constitución francesa de 1875 que no reconocía la popular, DUGUIT, León. Manual de Derecho constitucional. Madrid: Francisco Beltrán Librería española y extranjera, 1926, p. 403.

${ }^{17}$ CONCHA CANTÚ, Hugo Alejandro. La iniciativa legislativa popular. En: Sem organizador. Cuadernos Constitucionales México-Centroamérica: 19. La reforma constitucional en México y Argentina. México: Instituto de Investigaciones Jurídicas, 1996, p. 16. Disponible en: <https://archivos.juridicas.unam.mx/www/bjv/ libros/1/191/4.pdf>. Acceso el 12.02.2017.

${ }^{18} \mathrm{HAURIOU}$, Maurice. Principio de Derecho público y constitucional. Madrid: Editorial Reus, 1927, p. 132.

${ }^{19}$ HAURIOU, Maurice. Principio de Derecho público y constitucional. Madrid: Editorial Reus, 1927, p. 132.

${ }^{20}$ AGUIAR DE LUQUE, Luis. Democracia directa y Estado constitucional. Madrid: Edersa, 1977, p. 38, 43 y 44.
} 
la constitución, a instancia de 50.000 ciudadanos, y sirvió de referente para las primeras conceptualizaciones de la institución, vale destacar que no fue hasta la revisión total de la Constitución en 1874 que en Suiza se adoptó la ILP para el nivel federal.

Para el Maestro de Burdeos, la ILP significó la transformación del antiguo derecho de petición, a la vez que adquirió un carácter coactivo sobre las autoridades gubernamentales. Sobre la base de su regulación en Suiza, la apreció junto al reclamo del referéndum de una ley votada por el legislativo, como un medio de colaboración directa del cuerpo de ciudadanos en la formación de la ley, al poder reclamar del legislativo el estudio y la deliberación de una ley sobre determinada materia, a reserva de someterla, una vez votada, a referéndum ${ }^{21}$.

George Jellinek también se basó en la experiencia suiza y en la de algunos estados de Norteamérica, y convirtió su carácter vinculante en elemento definitorio, al decir que en virtud de la ILP "Ios sujetos legisferantes tiene que seguir las formas prescritas en el referéndum, de modo que la última decisión se reserva al pueblo"22. Por su parte, Hans Kelsen tiene en cuenta lo preceptuado en el artículo 41.2 de la Constitución Federal Austriaca de 1920 y sienta nuevas pautas para la definición de la ILP, ya que vio en esa regulación la posibilidad de que el pueblo tuviera cierta injerencia directa al efecto de formar la voluntad del Estado, para el Maestro de Viena, la institución se configuraba a partir de que un "determinado número de ciudadanos con derecho al sufragio puede presentar una proposición de ley, a cuya tramitación procedimental viene obligado el Parlamento" 23 .

Carl Schmitt se anticipa al afirmar que lo directo en la participación puede tener diverso grado y diverso volumen y aprecia la necesidad de distinguir diversas especies de procedimiento legislativo en la Democracia Directa. Schmitt toma como base la regulación de la ILP en el artículo 73 de la Constitución del Imperio Alemán de 1919 (Constitución de Weimar) y parte del presupuesto de que "el concepto democrático de Ley es un concepto político, no un concepto de ley propio del Estado de Derecho"24.

Bajo el rubro «Procedimiento legislativo de la Democracia directa», distingue el procedimiento de legislación popular, del acuerdo de ley por decisión popular a iniciativa del Gobierno, y del referéndum. El primero que interesa al efecto de distinguirlo de la ILP, "comienza por una iniciativa popular, y el acuerdo de ley se adopta por una votación popular. Este procedimiento legislativo popular se caracteriza porque en él no participan, o participan sólo como órganos auxiliares, las autoridades del

\footnotetext{
${ }^{21}$ HAURIOU, Maurice. Principio de Derecho público y constitucional. Madrid: Editorial Reus, 1927, p. 133.

22 JELLINEK, Georg. Reforma y mutación de la Constitución. Madrid: Centro de Estudios Constitucionales, 1991, p. 89.

${ }^{23}$ KELSEN, Hans. Valor y esencia de la democracia. Oviedo: KRK ediciones, 2006, p. 115.

${ }^{24}$ SCHMITT, Carl. Teoría de la Constitución. Madrid: Alianza Universidad Textos, 1992, p. 252.
} 
Estado y la Representación popular"25, mientras que bajo el rubro de iniciativa democrática de la ley, para Schmitt, la ILP es la promoción de una ley por una parte de los ciudadanos con voto, y se inscribe como un esfuerzo hacia la participación directa de los electores ${ }^{26}$.

\subsection{Criterios para su clasificación}

La clasificación de la ILP es una cuestión trascendente en su tratamiento teórico. Una de las más comunes se ha relacionado con la capacidad decisoria del cuerpo electoral respecto al proyecto de ley o a las normas objeto de la iniciativa que presenta una fracción del mismo. Esta valoración ha traído dos variantes: la directa en la que la intervención del Estado, a través de su órgano legislativo u otros en colaboración con este, ha quedado reducida a comprobar y validar el cumplimiento de las formalidades y la constitucionalidad de la iniciativa promovida por los ciudadanos, y son estos quienes aprueban o rechazan el proyecto de ley en una consulta popular vinculante, y la indirecta en la que el anteproyecto queda a merced de la decisión del órgano legislativo, el cual puede rechazarlo o aprobarlo incluso con modificaciones.

Esta última variante, en la que una parte -predeterminada en la ley- de los ciudadanos con derecho al sufragio, plantea una propuesta normativa al legislador, responsable último de la decisión final sobre esa iniciativa surgida "desde abajo"27, ha sido calificada como una «iniciativa de agenda». Como se afirmó, para la Teoría política ha trascendido considerar qué es o no una institución de democracia directa, y si bien ha relacionado la ILP con la iniciativa de agenda, algunos autores han dado un tratamiento particular a esta última, al efecto de diferenciarla de una ILP "autónoma", en la que solo se configura, en los términos de «democracia directa» y desde una concepción minimalista, si preceptivamente interviene la ciudadanía a través del voto en una consulta popular, para aprobar o no el proyecto de ley, de reforma o enmienda a la Constitución, o de normas, aunque vale reconocer que incluso en esta variante puede darse un riguroso trabajo parlamentario a fin de completar y aprobar las leyes propuestas por las ciudadanía.

Altman sostiene que la ILP en la que los ciudadanos presionan al legislativo para que considere una proposición de ley o de acto legislativo, representa en realidad un control sobre la agenda legislativa más que una herramienta para el cambio políti$\mathrm{CO}^{28}$. Para el International IDEA, Direct Democracy Handbook, la limitación fundamental

\footnotetext{
${ }^{25}$ SCHMITT, Carl. Teoría de la Constitución. Madrid: Alianza Universidad Textos, 1992, p. 252 y 253.

${ }^{26}$ SCHMITT, Carl. Teoría de la Constitución. Madrid: Alianza Universidad Textos, 1992, p. 257.

${ }^{27}$ SUÁREZ ANTÓN, Orestes; WELP, Yanina. ¿Cambio o cumbia? Análisis de la iniciativa de agenda en América Latina. Revista Boliviana de Ciencias Políticas, [s.I.], vol. 1, n. 1, p. 79-107. 2017, p. 81.

${ }^{28}$ ALTMAN, David. Direct democracy worldwide. New York: Cambridge University Press, 2014, p. 17.
} 
de esta configuración radica que el poder ciudadano, esencia de las instituciones de democracia directa, queda circunscrito al establecimiento de la agenda legislativa, al quedar, completamente, del lado del órgano legislativo el poder de decisión sobre la propuesta $^{29}$.

Desde esta óptica y teniendo en cuenta los orígenes de la institución en Suiza, la iniciativa de agenda es una derivación normativa posterior y degenerada de la ILP; pudiera considerarse una regresión matizada al antiguo «derecho de petición», pero sin los ruegos ni las súplicas, y siempre con un carácter público, por la naturaleza de los asuntos que se ventilan a través de ella.

Otro criterio determinante para la clasificación de la ILP ha sido la forma que adquiere el escrito de solicitud, será de tipo simple la que se limita a movilizar al órgano legislativo ordinario para que legisle sobre determinada cuestión, lo que recibe el legislativo es una propuesta genérica de ley, mientras que será de tipo formulada cuando medie la elaboración de un proyecto de ley por sus promotores ${ }^{30}$.

También ha interesado la jerarquía de la disposición normativa que se promueve con la iniciativa o la extensión del contenido normativo. Concha Cantú refiere a una iniciativa legislativa cuando la promoción de los ciudadanos es de una ley en sentido formal, o constitucional cuando acarrea la reforma parcial o la enmienda a la Constitución ${ }^{31}$. También con carácter extensivo, serían objeto de una iniciativa legislativa las disposiciones normativas de menor jerarquía, correspondientes a los niveles inferiores del poder público ${ }^{32}$, igualmente cabría hablar de iniciativa normativa cuando se refiera únicamente a modificar normas específicas de una ley en vigor (esta alternativa pudiera derivarse de la regulación de la institución en Ecuador y Uruguay).

\footnotetext{
${ }^{29}$ INTERNATIONAL INSTITUTE FOR DEMOCRACY AND ELECTORAL ASSISTANCE. Direct Democracy Handbook. Stockholm: International Institute for Democracy and Electoral Assistance, 2008, p. 84.

${ }^{30} \mathrm{CONCHA}$ CANTÚ, Hugo Alejandro. La iniciativa legislativa popular. En: Sem organizador. Cuadernos Constitucionales México-Centroamérica: 19. La reforma constitucional en México y Argentina. México: Instituto de Investigaciones Jurídicas, 1996, p.15-16. Disponible en: <https://archivos.juridicas.unam.mx/www/bjv/ libros/1/191/4.pdf>. Acceso el 12.02.2017; GARCÍA PELAYO, Manuel. Derecho constitucional comparado. Madrid: Alianza Editorial, 1984, p. 183-184; DUVERGER, Maurice. Instituciones políticas y Derecho constitucional. 6. ed. Barcelona: Editorial Ariel, 1988, p. 81.

${ }^{31}$ CONCHA CANTÚ, Hugo Alejandro. La iniciativa legislativa popular. Disponible en: <https://archivos.juridicas. unam.mx/www/bjv/libros/1/191/4.pdf>. Acceso12/02/2017. p. 15.

${ }^{32}$ México, Perú, y Colombia contemplan la iniciativa popular normativa de las entidades territoriales (además de la presentación de proyectos legislativos), Brasil la prevé constitucionalmente para el régimen estadal y la desarrolla en ley, Nicaragua reconoce las iniciativas de ordenanzas y resoluciones ante el Consejo Municipal y los Consejos Regionales de la Costa Atlántica, y República Dominicana refiere a la iniciativa legislativa municipal en su Carta Magna.
} 


\section{EL EXAMEN PROCEDIMENTAL DE LA INICIATIVA LEGISLATIVA POPULAR}

La ILP, al margen del debate acerca de cuál de sus derivaciones deben ser calificada como tal, o cuál debe ser o no considerada una institución de democracia directa, no deja de ser, primero, una institución democrática, en el sentido que apunta a la democratización del procedimiento legislativo y por ende, de la toma de decisiones políticas; y segundo, una fase o etapa dentro de este, dentro de la cual podría, incluso, evaluarse un grupo de subfases o subetapas perfectamente identificables.

No hay un tratamiento unitario respecto a la denominación del conjunto de acciones encaminadas a producir un ordenamiento legal o decreto del órgano legislativo, de ahí que es usual que en la doctrina se use indistintamente proceso o procedimiento ${ }^{33}$. Mendoza Díaz llama la atención que el tratamiento indistinto de estas dos categorías se ha extendido a la ley y al lenguaje forense ${ }^{34}$.

Sin embargo, el criterio de procedimiento legislativo se sostiene sobre la base de que para la creación de una ley, los órganos competentes siguen actos ordenados, y para algunos autores el concepto proceso es consustancial a la actividad jurisdiccional, o sea, no existe proceso fuera de los tribunales. El término procedimiento es más amplio, de cierta manera se emplea por defecto, siempre que se pretenda denotar una consecución de actividades que se suceden en diferentes ámbitos, como es el procedimiento legislativo o el electoral, aunque dentro del propio proceso tiene una connotación teórica propia ${ }^{35}$.

No obstante, no han faltado esfuerzos por diferenciarlos, como es el caso de José Antonio Da Silva que sostiene que por "proceso legislativo se entiende el conjunto de actos (iniciativa, enmienda, votación, sanción, veto) realizados por los órganos legislativos, para la formación de las leyes constitucionales, complementarias y ordinarias, resoluciones y decretos legislativos", mientras que el "procedimiento legislativo es el modo por el cual se realizan esos actos del proceso legislativo"36.

\footnotetext{
${ }^{33}$ FERNÁNDEZ RUIZ, Jorge. Poder legislativo. 2. ed. México: Porrúa-UNAM, 2004, p. 433. A los ejemplos de Fernando Santaolalla y de Carpizo y Madrazo, de la teoría constitucional mexicana, quienes utilizan el término procedimiento legislativo en vez de proceso, y de Andrea Manzella quien utiliza indistintamente uno u otro, traídos por el propio Fernández Ruiz, se suman los de QUIROGA LAVIÉ, Humberto. Derecho Constitucional Latinoamericano. México: UNAM, 1991, p. 341; GUASTINI, Riccardo. Estudios de Teoría Constitucional. México: Fontamara, 2001 (a lo largo de toda la obra) y LOEWENSTEIN, Karl. Teoría de la Constitución. 2. ed. Barcelona-Caracas-México: Ariel, 1979, p. 268, quienes se inclinan por usar procedimiento.

Por otra parte se emplea el término proceso legislativo en VANOSSI, Jorge Reynaldo. Estudios de Derecho Constitucional. México: UNAM, 2002, p. 208 y 286 y en MENDES, Gilmar Ferreira; BRANCO, Paulo Gonet. Curso de Direito Constitucional. 9. ed. São Paulo: Saraiva, 2014, p. 890.

${ }^{34}$ MENDOZA DÍAZ, Juan. Derecho procesal. Parte general. La Habana: Félix Varela, 2015, p. 168.

${ }^{35}$ MENDOZA DÍAZ, Juan. Derecho procesal. Parte general. La Habana: Félix Varela, 2015, p. 169-170.

${ }^{36}$ SILVA, José Alfonso da. Curso de Direito Constitucional positivo. 37. ed. São Paulo: Malheiros, 2013, p. 528 y 534. Traducción del autor.
} 
Consecuentemente con lo anterior, el procedimiento legislativo lo integra un conjunto de actos articulados con un propósito específico, como es, en el caso que ocupa, la elaboración y expedición de las normas jurídicas ${ }^{37}$. En la medida que tales actos no se realizan simultáneamente, sino por fases o etapas, diferentes autores las identifican de manera más o menos similar; así para Hevia de la Jara consta de tres etapas: iniciativa, en la que diferentes actores presentan una propuesta; constitutiva, que transcurre específicamente dentro del Parlamento; e integrativa de eficacia, relaciona con los procedimientos del Ejecutivo para vetar o publicar la norma legal ${ }^{38}$; Pérez Royo identifica la iniciativa, la discusión y la aprobación por las Cámaras e integración de la eficacia de la norma ${ }^{39}$; por su parte Fernández Ruiz refiere las etapas de iniciativa, dictamen, discusión, aprobación, promulgación e iniciación de la vigencia ${ }^{40}$; para Fernández Bulté, exponente de la teoría cubana, las fases son iniciativa, discusión, aprobación, promulgación, publicación y entrada en vigor ${ }^{41}$; Carpizo y Madrazo desagregan el procedimiento en iniciativa, discusión, aprobación, sanción, publicación e iniciación de la vigencia ${ }^{42}$.

La iniciativa es constante en la desagregación del procedimiento legislativo de estos autores, en la medida que constituye, indiscutiblemente, la primera fase del procedimiento legislativo. Un análisis en sede de la ILP permitirá desagregarla en requisitos y actos jurídicos que integrarían sus propias fases. Si bien las fases con sus actos y requisitos que se describen se corresponden a ILP que tiene como objetivo producir la ley en sentido formal, de manera general es compatible, mutatis mutandis, con las iniciativas populares de reforma y enmienda a la Constitución.

Fase promocional o de suscripción: se provoca al órgano legisferante y se interviene en su agenda legislativa y/o en parte de su dinámica funcional dentro del procedimiento legislativo.

Los requisitos a considerar son la legitimación para promover la iniciativa (quiénes y cuántos pueden promoverla); el órgano receptor (ante quién se promueve la iniciativa); las formalidades del documento contentivo de la iniciativa para que se considere admitida; los límites materiales o temporales ${ }^{43}$; las causas de inadmisión, dentro

\footnotetext{
${ }^{37}$ FERNÁNDEZ RUIZ, Jorge. Poder legislativo. 2. ed. México: Porrúa-UNAM, 2004, p. 433.

${ }^{38} \mathrm{HEVIA}$ DE LA JARA, Felipe. La iniciativa legislativa popular en América Latina. Revista Convergencia, México, vol. 17, n. 52, p. 155-185, ene./abr. 2010, p. 160.

${ }^{39}$ PÉREZ ROYO, Javier. Curso de Derecho constitucional. 4. ed. Madrid: Marcial Pons, 1997, p. 541.

${ }^{40}$ FERNÁNDEZ RUIZ, Jorge. Poder legislativo. 2. ed. México: Porrúa-UNAM, 2004, p. 433-434.

${ }^{41}$ FERNÁNDEZ BULTÉ, Julio. Teoría del Estado. La Habana: Félix Varela, 2001, p. 78-93.

${ }^{42}$ CARPIZO, Jorge; MADRAZO, Jorge. Derecho constitucional. México: UNAM, 1991, p. 86.

${ }^{43}$ Este límite existe en algunos ordenamientos donde se prevé que una vez sustanciada la iniciativa, o sea tramitada con rechazo o aprobación, no puede activarse otra con el mismo objeto hasta dentro de un tiempo determinado. En el art. 272 del Código electoral de Paraguay se imposibilita para la misma legislatura, dentro de los 2 años posteriores; en el último párrafo del art. 141 de la Constitución nicaragüense se advierte que las iniciativas de ley presentadas en una legislatura, si fueren rechazadas no podrán ser consideradas en la misma
} 
de las cuales destacan los juicios de legalidad (vinculados a los límites por ejemplo) y de constitucionalidad. Dentro de los actos relevantes de esa fase están la promoción de la iniciativa, a través del escrito de solicitud, la recepción del escrito de solicitud, la identificación del promotor o del comité de promoción, en los ordenamientos que lo permitan y la posibilidad de subsanar defectos detectados o apelar alguna decisión relacionada con la iniciativa

Fase de recolecta de firmas: los promoventes pretenden alcanzar el umbral mínimo de legitimidad requerido, para que el órgano legislativo decida siguiendo el procedimiento legislativo, o para que lo haga el cuerpo electoral a través de una consulta popular.

Dentro de esta subfase se encuentran la publicidad de la iniciativa y la recolecta y comprobación-autenticación de las firmas, así como la posibilidad de apelar la decisión relacionada con su conteo. Los requisitos serían el mínimo de firmas requerido y su distribución territorial en caso de exigirse; las formalidades que deben seguir los promoventes para su recolecta; y el plazo y prórrogas -en caso de admitirse- para la misma.

Fase de tramitación y decisión: el anteproyecto de ley se convierte en proyecto, el mismo es tratado en sede del órgano parlamentario, de manera similar al resto de las iniciativas legislativas de los otros actores legitimados, y/o se convoca a una consulta popular para que la ciudadanía decida sobre el proyecto.

Los requisitos y/o actos jurídicos a considerarse serían la validación del anteproyecto y su conversión en proyecto de ley ${ }^{44}$; la comparecencia y defensa del proyecto ante la comisión examinadora o el órgano parlamentario; el plazo para el tratamiento legislativo (con trámite de urgencia, si así se estipula); el tratamiento dentro del órgano parlamentario (votación y aprobación), o la convocatoria a la consulta popular vinculante del proyecto de ley.

\section{SITUACIÓN ACTUAL DE LA REGULACIÓN DE LA INICIATIVA LE- GISLATIVA POPULAR EN AMÉRICA LATINA. PROPUESTA PARA UNA TIPOLOGÍA}

En la mayoría de los ordenamientos latinoamericanos la ILP adquiere jerarquía constitucional, en ese orden se opta por su mero reconocimiento ${ }^{45}$ (Paraguay 1992,

\footnotetext{
legislatura; similar solución contempla el art. 77 de la Ley Orgánica del Poder Legislativo de Honduras; y el art. 107 de la Constitución dominicana establece que los proyectos de ley rechazados en una cámara, no pueden presentarse en ninguna de las dos cámaras hasta la legislatura siguiente.

${ }^{44}$ En la ILP, técnicamente lo que contiene el escrito de solicitud de los promoventes es un anteproyecto de ley, que solo se convierte en proyecto de ley cuando cumple las formalidades requeridas, vence los juicios de legalidad y constitucionalidad, reúne las firmas, estas son validadas y es aceptado formalmente por el órgano legislativo para integrarse el resto del procedimiento legislativo.

${ }^{45}$ Mero reconocimiento significa que la Constitución solo refiere a la institución y no establece ninguno de sus requisitos, ni tan siquiera las firmas necesarias para activar la iniciativa.
} 
Perú 1993 y Bolivia 2009) o además, por establecerse a ese rango requisitos que aseguren su materialización en mayor (Ecuador 2008) ${ }^{46}$ o menor medida (Colombia 1991 y Argentina 1994). Su complementación en leyes de desarrollo ha sido a través de una norma especial para la institución, dentro de una ley de participación o del Código electoral.

Los reglamentos de los órganos legislativos también integran la regulación de la ILP, a la vez que las normas de desarrollo regulan los actos propios de la iniciativa popular y remiten a lo dispuesto por estos en lo relativo a las demás fases del procedimiento legislativo; incluso pueden completar su regulación otras disposiciones que normen cuestiones específicas de la realización de la institución ${ }^{47}$.

En el anexo de este trabajo se consigna el año de la primera regulación constitucional de la ILP y/o de reforma a la Constitución (se incluye a la enmienda) en la Carta Magna de los 16 países latinoamericanos que en la actualidad reconocen la institución, los preceptos de la Constitución que regulan la ILP y/o la de reforma o enmienda constitucional; las normas complementarias que han desarrollado la institución, con su respectivo año de aprobación. El análisis de esa legislación permitió arribar a las siguientes conclusiones:

1- Dieciséis ordenamientos jurídicos latinoamericanos han reconocido la ILP en algunas de sus variantes, en sus constituciones, desde 1934 hasta el 2012 (año que corresponde al último reconocimiento de la institución que fue en México); de estos, siete ordenamientos $^{48}$ (Brasil 1988, Colombia 1991, Paraguay 1992, Perú 1993, Guatemala 1993, Argentina 1994 y Nicaragua 1995) la previeron entre finales de la "Tercera ola democrática" e inicios de la cuarta. Con el mismo rango normativo, cuatro lo hicieron prematuramente, dos en la primera mitad del siglo XX (Uruguay $1934^{49}$ y Cuba 1940) y

\footnotetext{
${ }^{46}$ La Constitución ecuatoriana no solo establece el mínimo de firmas requerido para activar la iniciativa legislativa, que es la lógica seguida por la mayoría de las constituciones del área, sino que además regula otros requisitos necesarios, incluso de naturaleza procedimental, para poner en práctica la institución.

${ }^{47}$ En Ecuador el Consejo Nacional Electoral reglamenta el proceso de recolección de firmas de cada jurisdicción (art. 7-II§, Ley Orgánica de Participación Ciudadana), la Ley Orgánica de Garantías Jurisdiccionales y de Control de Constitucionalidad se ocupa de la constitucionalidad de las propuestas de iniciativa popular que incida en el orden jurídico (arts. 100 y 126) y la Ley Orgánica Electoral. Código de la Democracia resuelve lo relativo a los derechos administrativos y los recursos judiciales electorales en el marco de las instituciones de democracia directa, y por ende de la ILP (art. 186); en México la Ley General del Sistema de Medios de Impugnación en Materia Electoral trata lo relativo a las impugnaciones que pueden suscitarse en los límites de la institución (art. 43 Ter.), mientras que el Código Federal de Instituciones y Procedimientos Electorales en Materia de Iniciativa Ciudadana e Iniciativa Preferente lo relativo a las firmas (arts. 128.3-4); en República Dominicana la Junta Nacional Electoral reglamenta lo relativo al procedimiento interno de la institución en su seno (Disposición Transitoria Única, Ley 136/2015).

${ }^{48}$ Cuando a continuación se relacionan los países seguido del año, se hace referencia a la primera constitucionalización de la ILP para el nivel nacional, entendida como iniciativa de ley formal y de reforma y/o enmienda a la Constitución.

${ }^{49}$ En el caso prematuro de Uruguay se reconoció la iniciativa popular de reforma de la Constitución (art. 284-A), mientras que la iniciativa popular legislativa quedó reducida a nivel local (art. 72).
} 
otros dos en la segunda (Venezuela 1961 y Ecuador 197850); por último, cinco países lo han hecho tardíamente, entre inicios de la primera y mediados de la segunda década del siglo XXI (Costa Rica y Bolivia 200251 , Honduras 2003, República Dominicana 2010 y México 2012). Panamá, Chile y El Salvador restan por reconocer en sus ordenamientos la iniciativa legislativa o de reforma a la constitución con origen popular, para el nivel nacional.

2- Tres ordenamientos complementan en la actualidad su regulación ${ }^{52}$, a través de una norma especial propia de la institución (Costa Rica, Argentina y República Dominicana), seis dentro de una ley de participación (Brasil, Colombia, Perú, Nicaragua ${ }^{53}$, Ecuador y Honduras), uno en los límites del Código electoral (Paraguay); mientras que Cuba, y México la desarrollan en el reglamento de su órgano parlamentario. Por su parte Bolivia, si bien vuelve a reconocer la institución en la Ley 026/2010 “Ley del Régimen Electoral", no desarrolla en la misma los extremos de la institución; Uruguay y Venezuela llenan los extremos principales del procedimiento de la iniciativa de enmienda y de reforma constitucional en la propia Carta Magna, no así el de la ILP54; Guatemala no ha desarrollado el procedimiento a seguir para la iniciativa de reforma constitucional.

3- Ocho constituciones prevén en la actualidad la iniciativa popular de ley ordinaria o formal, junto a la de reforma y/o enmienda constitucional (Uruguay, Colombia, Paraguay, Perú, Venezuela, Costa Rica, Ecuador y Bolivia). Por su parte, Guatemala solo reconoce la iniciativa popular de reforma constitucional, mientras que Cuba, Brasil, Argentina, Honduras, Nicaragua, República Dominicana y México, no reconocen la iniciativa popular de reforma o enmienda constitucional, en Cuba, al menos taxativamente.

4- Los límites materiales que comúnmente se establecen para la ILP en América Latina son: políticas o relaciones internacionales (Colombia, Paraguay, Argentina, República Dominicana); materia presupuestaria (Colombia, Perú, Argentina, Costa Rica y República Dominicana), materia tributaria (Uruguay, Paraguay, Colombia, Perú, Ecuador,

\footnotetext{
${ }^{50}$ La Constitución ecuatoriana de 1967 hizo un reconocimiento indirecto que a la postre terminó siendo antinómico de la ILP, al preceptuarla primero en su capítulo VII como un derecho político (los ciudadanos ecuatorianos tienen derecho a la elaboración de leyes), pero al relacionar en el artículo 145 quienes tenían iniciativa legislativa, el anterior precepto no encontró consecución al no hacer referencia a los ciudadanos. MORALES VITERI, Eduardo. Ecuador: mecanismos de democracia directa. Disponible en: <www.zora.uzh.ch/95761/1/ C2D_WP20.pdf>. Acceso el 24.11.2017. p. 10 y 11.

${ }^{51}$ Por Ley № 2410 del 8 de agosto del 2002 se adicionó al procedimiento legislativo. Artículo 71-III: Los ciudadanos podrán presentar directamente al Poder Legislativo proyectos de ley en cualquier materia. La Ley determinará los requisitos y procedimientos para su consideración obligatoria por el órgano correspondiente.

${ }^{52}$ En esta parte solo se reconocerá a las normas complementarias por sus siglas, en el ANEXO de este trabajo estas normas se encuentran debidamente identificadas con su denominación legal y sus respectivas siglas.

${ }^{53}$ Nicaragua hasta 1997 lo hizo a través de una norma especial para la institución, Ley № 269/1997 “Ley de Iniciativa de Leyes", que fue derogada por la Ley № 475 "Ley de Participación ciudadana".

${ }^{54}$ En Venezuela la ordenación de la participación popular y el poder popular establecido en la Ley Orgánica del Poder Popular de 2010, la Ley Orgánica del Poder Ciudadano de 2011, la Ley Orgánica del Poder Municipal, no se pronuncia sobre la ILP.
} 
Costa Rica, República Dominicana); la reforma constitucional de manera expresa (Argentina, Nicaragua ${ }^{55}$ y República Dominicana).$^{56}$

Los límites explícitos a la reforma de la Constitución son diferentes a los límites materiales que se imponen a la ILP, pues cumplen entre sus finalidades, a decir de Pedro de Vega, la de asentar en el más alto nivel normativo, "los supuestos ideológicos y valorativos en los que descansa el régimen político que con la Constitución se pretende establecer" ${ }^{\prime \prime}$.

No se prevén límites materiales a la iniciativa legislativa en Cuba, México y Honduras, vale acotar que en estos países debe inferirse como límite implícito la reforma constitucional, aunque en el primer caso pudiera resultar polémico.

La regulación de la ILP en los dieciséis ordenamientos latinoamericanos, permite sistematizar una tipología que evidencia cómo la relación entre el principio democrático y el representativo, influye en mayor o menor grado en su diseño institucional. Siendo la ILP una típica institución que se activa "desde abajo", la mayor incidencia del principio democrático asegurará no solo la participación y control de los ciudadanos en las diferentes fases del procedimiento de la institución, sino también la capacidad del cuerpo electoral para determinar el resultado final de la decisión política.

De manera contraria, una marcada incidencia del principio representativo, puede reducir esta institución a su perfil de iniciativa de agenda legislativa, o a variantes donde el control estatal termine asfixiando las intenciones de los promoventes y de la ciudadanía en general. Como quiera que sea, la ILP, sobre la base de la interacción de estos dos principios, tendrá una graduación o progresión más o menos democrática en su diseño, sin que esto determine su puesta en práctica. A partir de lo anterior, se relacionará la tipología (alternativas y derivaciones) que puede presentar la institución, en la mayoría de los casos se hará acompañar de su respectivo ejemplo.

Alternativa 1: proyecto de ley o propuesta de normas de reforma o enmienda constitucional, que al cumplir los requisitos formales y alcanzar el umbral de legitimidad, el órgano legislativo lo conoce e integra al procedimiento legislativo ordinario o

\footnotetext{
${ }^{55}$ Llama la atención como los límites materiales de la ILP en Nicaragua se ampliaron con la Ley № 475 “Ley de Participación ciudadana" (véanse arts. 9 y 10), al adicionarse a las determinadas en el apartado 5 del artículo 140 constitucional (leyes orgánicas, tributarias, de carácter internacional y las de amnistía y de indultos) las leyes del Presupuesto General de la República, las de rango constitucional y la Constitución de la República, las relativas a la defensa y seguridad nacional y los Códigos de la República.

${ }^{56}$ Algunos ordenamientos apuestan por excluir indirectamente determinadas materias de la ILP, al disponer en la Constitución, la exclusividad del ejecutivo sobre un grupo de estas, Uruguay (arts. 79-II§, 86-III§ y 133II§), Colombia (arts. 154-II§ y 150); Brasil (art. 61.1) y Ecuador (art. 135) por ejemplo. Otra manera de excluir indirectamente determinadas materias de la ILP es aludiendo a las limitaciones que presenta el referendo y haciéndolas valer para ella, como es el caso de Paraguay (arts. 267 y 122, Const.).

${ }^{57}$ DE VEGA, Pedro. La reforma constitucional y la problemática del poder constituyente. Madrid: Tecnos, 1985, p. 248.
} 
extraordinario, para aprobarlo o rechazarlo en votación plenaria ${ }^{58}$ (Cuba, Colombia, Argentina, Costa Rica, México, Guatemala, Paraguay, Perú, Nicaragua, Honduras, Brasil, Venezuela y República Dominicana) ${ }^{59}$.

Se desprenden de esta alternativa las siguientes derivaciones:

Derivación 1.1: El órgano legislativo vota en contra del proyecto, o no lo tramita en el término legalmente establecido, y se procede preceptivamente a una votación popular (Venezuela: ILP arts. 204 y 205, Const., cuando no es tramitado).

Derivación 1.2: El órgano legislativo vota en contra del proyecto, o lo modifica sustancialmente, o no lo tramita en el término legalmente establecido, y los promoventes pueden solicitar una consulta popular ${ }^{60}$ (Ecuador: IPRC art. 103-IV§, Const. e ILP art. 11, Ley Orgánica de Participación Ciudadana).

Derivación 1.3: El órgano legislativo vota en contra del proyecto y los promoventes pueden completar el número de firmas establecido para el referendo, con el objetivo de que la ciudadanía decida aprobar o no el proyecto de ley rechazado por el órgano parlamentario (Perú: ILP arts. 16 y 41, Ley N²6.300/1994).

Derivación 1.4: El órgano legislativo vota a favor del proyecto o de la propuesta de normas para una enmienda o reforma de la Constitución, no obstante debe someterlo a referendo. Esta derivación es propia de las reformas o enmiendas a la Constitución y busca dotar de la mayor legitimidad posible a la decisión político-constitucional (Colombia: IPRC art. 377, Const.; Venezuela: IPRC art. 343-345, Const.; Guatemala: IPRC arts. 277-d y 280 Const.).

Alternativa 2: proyecto de ley o propuesta de normas de reforma o enmienda constitucional que se presenta al órgano legislativo y al cumplir los requisitos exigidos legalmente y alcanzar el umbral de legitimidad, es sometido directamente a votación popular (Uruguay, Ecuador, Venezuela) El órgano representativo es subrogado por el

\footnotetext{
${ }^{58}$ ILP hace referencia a iniciativa legislativa popular, mientras que IPRC e IPEC a iniciativa popular de reforma constitucional y de enmienda constitucional, respectivamente.

${ }^{59}$ Véanse en los casos de Cuba (ILP: art. 68-c, Reglamento de la Asamblea Nacional del Poder Popular); Colombia 1991 (ILP: art. 141, y 143 y ss., Ley № 5/1992; IPRC: art. 377, Const.); Argentina (ILP: arts. 10 y 11, Ley № 24.747/1996); Costa Rica (ILP: art. 124-I y II§, Const.); México (ILP: art. 132-d Ley Orgánica del Congreso General; arts. 182.1.2, 204.1.2, Reglamento del Senado, y 80-II y 85-VII, Reglamento de la Cámara de Diputados); Guatemala (IPRC: arts. 277-d y 280 Const.); Paraguay (IPRC: art. 289, Const.; IPEC: art. 290 Const.; ILP: art. 269, Ley № 834/1996); Perú (IPRC: art. 18 y 206, Const.; ILP: art. 16, Const.); Nicaragua (ILP: art. 144, Ley No 475/2003); Honduras (ILP: arts. 51 y ss., Decreto 256/2013); Brasil (ILP: art. 14, Ley 9.709/1998; art. 252-VI, Res. № 17/1989 y demás normas aplicables al procedimiento ordinario del resto de las iniciativas); Venezuela: ILP: art. 205, Const. e IPRC: arts., 343-345, Const.; y República Dominicana (ILP: arts. 166 y ss., Reglamento del Senado).

${ }^{60}$ Esta última opción es lo que Hauriou apreció como el referéndum facultativo mezclado de iniciativa popular. Para él consistía "en el hecho de que son los ciudadanos y no la legislatura, quienes toman la iniciativa de la ley. Una petición suscrita también por algunos miles de firmas pone en movimiento el aparato de formación de la ley, y esta ley, una vez hecha por la legislatura (o una vez formulado el contraproyecto de ésta) se somete a referéndum y los ciudadanos deciden. HAURIOU, Maurice. Principio de Derecho público y constitucional. Madrid: Editorial Reus, 1927, p. 501.
} 
cuerpo electoral, al reducirse el rol del primero a un simple controlador de formalidades, o en algunas regulaciones a colegislador.

Derivación 2.1 Sin contrapropuesta o proyecto modificativo del órgano legislativo (Ecuador: IPEC, art. 13, Ley Orgánica de Participación Ciudadana; Venezuela: IPEC, art. 341.1.3, Const.).

Derivación 2.2 (al estilo suizo) Con contrapropuesta o proyecto modificativo del órgano legislativo (Uruguay: IRC, art. 331, inc. a, Const.).

La alternativa 1 corresponde a lo que en la Teoría política se identifica como la iniciativa legislativa indirecta (iniciativa de agenda). La primera opción de la derivación 1.1 (el legislativo vota en contra del proyecto y preceptivamente se procede a la consulta popular) no tiene precedente en la legislación latinoamericana), pero junto a la segunda opción de esta derivación y a las derivaciones 1.2 y 1.3 son variantes de la iniciativa legislativa que refuerzan la vis democrática de la institución, al potenciar el "decisionismo" ciudadano en el procedimiento y en la decisión política final. La derivación 4 es una iniciativa legislativa indirecta combinada, pues los promoventes deberán seguir un nuevo iter procedimental que conlleva a una consulta popular, pero que tiene como base de legitimidad lo hecho en los límites de la activación de la ILP.

Por su parte, la alternativa 2 constituye en puridad, una acción legislativa popular directa, a la vez que el órgano legislativo es reducido a un mero controlador de formalidades de la propuesta y facilitador de la iniciativa, aunque puede integrarse a la misma lanzando una contrapropuesta, a esta alternativa se le ha solido denominar, inexactamente, iniciativa legislativa directa ${ }^{61}$, y ha servido para conformar una definición de la institución.

\section{ALGUNOS PRINCIPIOS DEDUCIBLES DE LA REGULACIÓN DE LA INICIATIVA LEGISLATIVA POPULAR}

A decir de Fernández Ruiz los actos que configuran el procedimiento legislativo alcanzan cierta connotación procesal ${ }^{62}$, de ahí que los principios que se relacionarán se vinculan al procedimiento, y por lo tanto algunos de ellos tienen una vis procesal.

Como se ha venido sosteniendo, la iniciativa es una fase del procedimiento legislativo que integra una serie de actos preclusivos que se deben cumplir, para alcanzar una finalidad determinada: concretar un proyecto de ley para que sea votado por el órgano legislativo o popularmente, y previa aprobación pueda convertirse en decisión política general y obligatoria. Junto a los principios que se identifican vinculados al procedimiento, existen otros de naturaleza político-constitucional que informan a

\footnotetext{
${ }^{61}$ HEVIA DE LA JARA, Felipe. La iniciativa legislativa popular en América Latina. Revista Convergencia, México, vol. 17, n. 52, p. 155-185, ene./abr. 2010, p. 161.

${ }^{62}$ FERNÁNDEZ RUIZ, Jorge. Poder legislativo. 2. ed. México: Porrúa-UNAM, 2004, p. 433.
} 
todo el ordenamiento jurídico, como son el democrático, legalidad y participación, que igualmente se manifiestan en la parte del procedimiento de la ILP.

Al ser los principios jurídicos normas de optimización ${ }^{63}$, es posible sostener que en los ordenamientos jurídicos existen normas optimizadas las cuales desde una perspectiva teleológica, persiguen determinadas finalidades, y a la postre, sirven de referente para mejorar la calidad de normas que regulan instituciones o actos jurídicos similares, en otros ordenamientos jurídicos. Estos principios en sede de la ILP, informan a normas que tienden a facilitar la participación ciudadana, a dotar de eficacia y racionalidad jurídico-política a la institución, a reforzar el vínculo entre el órgano legislativo y la ciudadanía, y a garantizar la realización de la institución, sobre la base de criterios democráticos y de soberanía popular.

La relación que a continuación se hace de los principios que informan a la ILP, no obsta que puedan reconocerse otros que no han sido aquí considerados ${ }^{64}$; asimismo las normas jurídicas que se identifican para poner en evidencia cómo se expresan estos principios, no agotan la totalidad de los ejemplos que se pudiesen extraer de la regulación de la institución en América Latina, sin que esta última acotación signifique que existe una evidente homogeneidad en la regulación de la ILP en el área.

1. Principio de participación: es expresión directa del principio democrático. No debe verse únicamente como facilitador de la intervención ciudadana, al ser esta esencia natural de las instituciones participativas. El principio de participación debe proyectarse en una institución de este tipo, donde caben dinámicas representativas, sobre la base del apotegma de Maiofer que postula "tanta participación como sea posible, tanta representación como sea necesario"65.

Este principio en los límites de la ILP, puede verse a través de tres salidas normativas:

I- Prorrogabilidad del plazo para la recolecta de firmas: esta concesión facilita la participación ciudadana en la medida que más ciudadanos pueden involucrarse en la realización de la institución, así lo afirman Paraguay, donde los 180 días para la recolecta pueden dilatarse a 60 más, a solicitud de los promotores y si las firmas superan el 75\% al cumplirse el término establecido (art. 272, Ley No 834/1996); sin el último requerimiento de la ley paraguaya, Perú (art. 10, Ley No 26300/1994), República Dominicana (arts. 19-I§ y 20, Ley No 136/2015) y Costa Rica (art. 3-II§, Ley No 8491/2006), conceden 30 y 90 días más, a fin de que los promotores puedan completar el número de firmas.

\footnotetext{
${ }^{63}$ ALEXY, Robert. Teoría de los derechos fundamentales. Madrid: Centro de Estudios Constitucionales, 1993, p. 86.

${ }^{64}$ En este sentido no se abordarán una serie de principios que también informan la vis procedimental de la ILP como podrían ser los de preclusión, especialidad, eficacia, economía procesal en toda su extensión (se tratará en parte a través de la celeridad), representación y unidad de materia. Tampoco los principios político-jurídicos de legalidad y el democrático, este último en su carácter fundamentador de este tipo de instituciones.

${ }^{65}$ MAIHOFER, Werner. Principios de una democracia en libertad. En: BENDA, Ernesto et. al (Org.). Manual de Derecho Constitucional. Madrid: Marcial Pons, 1996, p. 266-277.
} 
II- Participación en la tramitación parlamentaria: esta salida del principio de participación permite a los promoventes, a través de uno o más representantes ligados directamente a sus intereses, defender con voz pero sin voto, su propuesta en el seno del órgano legislativo.

La participación en esta subfase tiene diferente graduación cuando se examina la institución en América Latina, las variaciones pueden ser de orden cuantitativo o cualitativo, en este último caso tiene que ver con cómo se participa (con voz y/o voto) y dónde se participa (ante una comisión o ante el plenario).

En Honduras 10 de los promoventes pueden participar con voz, pero sin voto en la discusión en el pleno (art. 13, Decreto No 190/2012); en México el representante designado por los promoventes podrá defender el proyecto ante una comisión de la cámara correspondiente, según sea el caso (art. 133, Ley Orgánica del Congreso General); y en Perú dos representantes de los promoventes lo harán ante las correspondientes comisiones y en el proceso de reconsideración (art. 14, Ley No 26300/1994). Por su parte, en Colombia el promotor de la iniciativa puede participar en todas las sesiones en que se trate el proyecto (art. 20, Parág. II, Ley Estatutaria No 1757/2002); en Ecuador los promoventes tienen derecho a participar directa o mediante representación, en el debate del proyecto, en comisión y en pleno de la Asamblea (arts. 103-II§ y 137-II§, Const.; art. 54, Ley Orgánica de la Función Legislativa); y en Brasil el primer firmante o quien este haya indicado puede hacerlo igualmente en comisión y en pleno (art. 252VII, Ley No 9.709/1998).

III- Consulta popular para aprobar o desestimar el proyecto de la ILP: el hecho de que la propuesta legislativa pueda ser votada popularmente constituye la expresión máxima del principio de participación en los límites de la institución. Existen diferentes vías para llegar a la consulta popular, lo que denota que el principio de participación puede incidir con diferente grado en la concepción normativa de la institución (véase en Venezuela la ILP, art. 205 Const.; en Ecuador, la IPRC, art. 103-IV§, Const.; y la ILP, art. 11, Ley Orgánica de Participación Ciudadana; en Uruguay, la IRC, art. 331-A, Const.)

2. Principio de gratuidad (minimización de gastos): tiene su fundamento en que la participación es un derecho humano que el Estado debe garantizar, por lo tanto, no puede convertirse en una carga económica para el ciudadano, más allá de la que normalmente implica la puesta en marcha de este tipo de mecanismo, pues como afirma Lissidini, al margen de las potencialidades de la iniciativa para movilizar el debate y empoderar a la ciudadanía, "requiere también capacidad de movilización, recursos económicos y humanos"66.

${ }^{66}$ LISSIDINI, Alicia. Democracia directa en América Latina. Buenos Aires: C2D, International IDEA, Escuela de Política y Gobierno UNSAM y Prometeo Libros, 2008, p. 16. 
Las manifestaciones de este principio se pueden encontrar en pocos ordenamientos latinoamericanos, en Paraguay donde los promoventes deben autenticar las firmas ante notario, el Estado resarcirá los gastos incurridos por cada elector, siempre que se apruebe el proyecto de ley (art. 273, Ley No 834/96); y en Perú si el proyecto deviene en ley, los promotores tienen derecho a solicitar el reembolso de los gastos efectuados ante la autoridad electoral, así como los incurridos para su difusión (art. 47, Ley No 26.300).

3. Principio de colaboración: se incardina con el de corresponsabilidad que comparten el órgano con función legislativa y la ciudadanía en la formación del estatuto legal del Estado, en el marco de un modelo que pretenda compatibilizar normativamente la representación política con la participación directa de los ciudadanos. La colaboración no se agota en las variantes de compensación económica vistas anteriormente, sino que se extiende a determinadas acciones de los órganos o instancias estatales para apoyar a los participantes en la ILP, por la naturaleza técnica de la actividad legislativa.

En Costa Rica, la Oficina de Iniciativa Popular de la Asamblea Legislativa y la Defensoría de los Habitantes ofrece asesoría gratuita a la ciudadanía para la redacción de proyectos y el procedimiento a seguir para la puesta en práctica de la institución (art. 4, Ley $\left.N^{\circ} 8.491 / 2006\right)$. En Brasil se prevé la coparticipación de un representante político en la tramitación parlamentaria del proyecto popular de ley, a la vez que un diputado con la anuencia del primer firmante del proyecto, ejercerá la defensa del proyecto de iniciativa popular ante el órgano legislativo (art. 252-X, Resolución No 17/1989 “Reglamento Interno de la Cámara de Diputados"). En República Dominicana la Comisión proponente podrá requerir las directrices, manuales, normas y procedimiento legislativos de los trámites internos de las cámaras legislativas (art. 15, Ley No 136/2015).

En Brasil, la colaboración que debe prestar el órgano legislativo para subsanar los vicios de forma en que incurran los promoventes en su escrito de solicitud es otra manifestación del principio de colaboración, se prohíbe que estos vicios sean invalidante de la iniciativa (art. 13-§ 20, Ley No 9.709/1998)

4. Principio de celeridad: desde el punto de vista procesal, se fijan normas destinadas a impedir la prolongación de los plazos y a eliminar trámites procesales superfluos u onerosos. En los límites del procedimiento legislativo, iniciado por la ciudadanía, tiene una connotación diferente, a la vez de que se trata de evitar dilaciones maliciosas por las instancias de poder que desmovilicen a la ciudadanía o trunquen la iniciativa legislativa.

Es expresión de este principio la previsión de mensajes de trámite de urgencias y/o preferencia para los proyectos de iniciativa popular. En Perú recibe preferencia en el trámite del Congreso (art. 11, Ley No 26.300/1994) al igual que en Argentina (art. 10-III§, Ley $N^{\circ}$ 24.747/1996); en Colombia pueden tener prelación, lo que es potestativo del Ejecutivo (arts. 155 y 163, Const.); en Paraguay su tratamiento es priorizado y el estudio 
correspondiente se iniciará sin demora en la Cámara (art. 270 y 271, Ley No 834/1996); en México conservará su carácter preferente durante todo el proceso legislativo (art. 138.2, Ley Orgánica del Congreso General).

También la celeridad se constata al establecerse un término para tratar o votar el proyecto, en Perú el Congreso dispone de 120 días para dictaminarlo y votarlo (art. 13, Ley $N^{\circ}$ 26.300/1994), en Ecuador la Asamblea dispone de 180 días para tratar la propuesta (art. 103, Const. y art. 66, Ley Orgánica de la Función Legislativa; en Argentina el Congreso deberá dar tratamiento expreso a la iniciativa en 1 año (art. 11, Ley $N^{\circ}$ 24.747/1996); y en Costa Rica la Asamblea dispone de 2 años para votarla, excepto si se trata de la reforma de la Constitución (art. 6, Ley No 8.491/2006). Otra alternativa es apelar a la participación directa ante la inactividad del legislativo, en Venezuela se activa el referendo ante la inacción de la Asamblea Nacional (art. 205, CRBV) y en Ecuador el proyecto entra en vigor ante igual situación (art. 103-II§, Const.; art. 66, Ley Orgánica de la Función Legislativa), aunque hasta el momento no haya sucedido, en este último país, no obstante cumplirse la hipótesis de la norma ${ }^{67}$.

5- Principio de impugnación: algunos ordenamientos prevén que los promoventes reclamen las decisiones de los órganos estatales relacionadas con la sustanciación de la iniciativa ${ }^{68}$. Al igual que el principio de participación es graduable ya que en algunos ordenamientos va de la posibilidad de apelar la decisión que determina el incumplimiento del total de firmas requeridas hasta otros que permiten apelar la que desestima la ILP por el pleno o la comisión.

En Ecuador, en caso de declararse no admisible el proyecto, la comisión popular puede solicitar el pronunciamiento de la Corte Constitucional, quien deberá hacerlo en un plazo de 30 días (art. 9-IV§, Ley Orgánica de Participación Ciudadana) ${ }^{69}$; en Costa Rica cualquier ciudadano puede impugnar los actos emitidos sobre el conteo, la verificación y la legitimidad de firmas, en la forma prevista por la ley (art. 3-III§, Ley No 8491/2006); en México si el Instituto Nacional Electoral determina con carácter definitivo que no se cumple con el porcentaje de firmas requerido, el representante de los promoventes puede impugnar la resolución ante el Tribunal Electoral del Poder Judicial de la Federación (art. 132, inc. c-II§, Ley Orgánica del Congreso General). Por su parte, en Colombia si la comisión negase la iniciativa, puede ser apelada por el comité promotor ante la plenaria (art. 20, inc. b-II§, Ley Estatutaria No 1757/2015).

\footnotetext{
${ }^{67}$ SUÁREZ ANTÓN, Orestes; WELP, Yanina. ¿Cambio o cumbia? Análisis de la iniciativa de agenda en América Latina. Revista Boliviana de Ciencias Políticas, [s.l.], vol. 1, n. 1, p. 79-107. 2017, p. 97 y 98.

${ }^{68}$ Aunque es una práctica extendida a la mayoría de los ordenamientos latinoamericanos, existen regulaciones que impiden a los promoventes impugnar las decisiones relacionadas con la sustanciación de la ILP adoptadas por los órganos estatales, por ejemplo en Paraguay la decisión del Presidente del Congreso que bajo resolución fundada, rechace la iniciativa, no admite recurso alguno (art. 269, Ley 834/1996), o en Cuba que no se regula en el Reglamento de la Asamblea Nacional del Poder Popular, posibilidad alguna de impugnar las decisiones. ${ }^{69}$ Para el caso ecuatoriano ver también el artículo 186 de la Ley Orgánica Electoral. Código de la Democracia.
} 
6- Principio de representatividad: garantiza la legitimidad de la acción ciudadana; este principio en sede de la institución toma como base la población electoral y en algunos ordenamientos, además el régimen territorial. Se pretende que la ILP alcance un umbral de legitimidad representativo del cuerpo electoral, y en los estados federados se pretende además que esta representatividad tenga una dimensión territorial por la propia implicación que este régimen tiene a los efectos de la representación. En ambos casos se evita que la iniciativa quede secuestrada en manos de un grupo ciudadano con intereses específicos y con capacidad movilizadora sobre una parte de la ciudadanía.

Relacionado con lo anterior, en Brasil se requiere la firma del $1 \%$ del electorado nacional, distribuido al menos en cinco estados, con no menos de $0,3 \%$ de los electores per cápita (art. 13, Ley №. 9.709/1998), mientras que en Argentina se requerirá la firma de al menos el 1,5\% del padrón electoral utilizado para la última elección de diputados nacionales y deberá representar por lo menos a seis distritos electorales (art. 4, Ley No 24.747/1998).

El umbral de legitimidad con base a la población electoral es una de las cuestiones discutidas, umbrales muy bajos pueden hacer activar al órgano electoral en función de una iniciativa popular, que no podrá reunir apoyo popular en el resto del procedimiento, y de manera inversa, umbrales muy altos la pueden hacer inoperante.

7- Principio de publicidad: tiene un estrecho ligamen con el de transparencia, ambos tributan al derecho a la información que tienen los ciudadanos que garantizan una participación oportuna, consciente y responsable. En Colombia el nombre de la iniciativa, de sus promotores y vocero, junto al texto del proyecto y la exposición de motivos, deberán ser divulgados en la publicación oficial del Congreso (art 19-II\$, Ley Estatutaria № 1.757/2015); en Perú se ordena la publicación del anteproyecto de la iniciativa en el Diario Oficial (art. 11, Ley № 26.300/1994); mientras que en República Dominicana, la comisión proponente manifestará en un aviso público, el impulso de la iniciativa, así como la metodología a seguir para la recolecta de firmas (art. 25, Ley No 136/2015).

Si bien, se han consignado un grupo de normas dentro de las regulaciones de la ILP en América Latina, a manera de ejemplos, es válido destacar que ordenaciones de esta institución como la brasilera, la colombiana, la ecuatoriana, la peruana y la nicaragüense son las que contienen la mayor cantidad de normas, que son expresión estos principios.

\section{CONSIDERACIONES FINALES (A MODO DE CONCLUSIÓN)}

La ILP en América Latina muestra en espectro amplio en su configuración normativa; existen diferentes variantes para que la ciudadanía participe directamente en la toma de la decisión política vinculada a la misma, lo que pone en evidencia la 
diferente graduación que puede alcanzar el principio democrático en esta institución jurídico-constitucional.

La expresión del principio democrático no solo admite graduación -aunque no deja de ser la principal- en las valoraciones del vínculo que se logre establecer entre la ciudadanía, el órgano legislativo y la toma de decisión política, sino que también es admisible en cuestiones específicas del procedimiento de la ILP, tales como la defensa del proyecto. No podría equipararse la posibilidad que dan algunos ordenamientos de que los promoventes o un representante de estos, defiendan el proyecto ante la comisión y el plenario, o en cualquier fase del procedimiento, con la defensa solo ante la comisión. En este sentido, cabría la graduación respecto a la incidencia de este principio, en la facultad que tienen los promoventes de impugnar determinadas decisiones relacionadas con la ILP frente a otros ordenamientos que no establecen previsiones similares; $\mathrm{o}$, en el número de firmas que se exige para alcanzar el umbral de legitimidad requerido para movilizar al órgano legislativo o la ciudadanía de cara a la propuesta, por solo citar tres ejemplos.

Si se parte de una concepción normativo-procedimental, afín con la perspectiva analítica del Derecho constitucional, la acción legislativa popular directa no debe ser tratada de la misma manera que la ILP, pues de cierta manera sería desnaturalizar la institución, a partir de que la iniciativa legislativa (popular o no) se integra al procedimiento legislativo, como una fase del mismo. Así lo reconocen los artículos 155 de la Constitución (Colombia); 271 de la Ley No 834/1996 (Paraguay); 14-II§ de la Ley No 475/2003 (Nicaragua); 27 de la Ley No 136/2015 (República Dominicana); 15 del Decreto No 190/2012 (Honduras); 4 de la Ley No 8491/2006 (Costa Rica); y 14 de la Ley No 9.709/1998 (Brasil). Como afirma el Reglamento del Congreso de Perú: “Las propuestas o proyectos de ley o de resolución legislativa son instrumentos mediante los cuales se ejerce el derecho de iniciativa legislativa y se promueve el procedimiento legislativo, con la finalidad de alcanzar la aprobación de una ley o resolución legislativa por el Congreso"70.

La diferente graduación que alcanza el principio democrático en sede de la ILP puede y de hecho incide en la valoración que se haga de la misma como una institución de democracia directa o semidirecta. No obstante, la salida dicotómica que algunos exponentes de teoría política dan a la ILP, al efecto de diferenciar la directa de la indirecta (iniciativa de agenda), no es suficiente para tratar a la institución en todos sus extremos, pues a estas se suman otras variantes como las de Perú, Ecuador, Colombia y Venezuela, algunas de estas vinculadas a la enmienda o reforma de la Constitución.

Los principios ordenadores del procedimiento de la ILP tributan a la democratización de la misma, a facilitar la participación ciudadana y en alguna medida, a la realización o puesta en práctica de la institución. En los ordenamientos latinoamericanos existe una tendencia a que la regulación de la iniciativa legislativa esté informada,

\footnotetext{
${ }^{70}$ Art. 67 del Reglamento del Congreso de la República de Perú, www.congreso.gob.pe/Docs/files/documentos/reglamento-15-07-2016.pdf. Acceso el 11/112017.
} 
principalmente por los principios de participación, colaboración, gratuidad, impugnación y celeridad.

\section{REFERENCIAS}

AGUIAR DE LUQUE, Luis. Democracia directa y Estado constitucional. Madrid: Edersa, 1977.

ALEXY, Robert. Teoría de los derechos fundamentales. Madrid: Centro de Estudios Constitucionales, 1993.

ALTMAN, David. Direct democracy worldwide. New York: Cambridge University Press, 2014.

CARPIZO, Jorge; MADRAZO, Jorge. Derecho constitucional. México: UNAM, 1991.

CONCHA CANTÚ, Hugo Alejandro. La iniciativa legislativa popular. En: Sem organizador. Cuadernos Constitucionales México-Centroamérica: 19. La reforma constitucional en México y Argentina. México: Instituto de Investigaciones Jurídicas, 1996. Disponible en: <https://archivos.juridicas.unam.mx/www/bjv/libros/1/191/4.pdf>. Acceso el 12.02.2017.

CONSTANT, Benjamin. De la libertad de los antiguos comparada con la de los modernos. Disponible en: <https://omegalfa.es/downloadfile.php?file=libros/discurso-de-la-libertad-de-los-antiguos-comparada-con-la-de-los-modernos.pdf $>$.

DE VEGA, Pedro. La reforma constitucional y la problemática del poder constituyente. Madrid:Tecnos, 1985.

DUGUIT, León. Manual de Derecho constitucional. Madrid: Francisco Beltrán Librería española y extranjera, 1926.

DUVERGER, Maurice. Instituciones políticas y Derecho constitucional. 6. ed. Barcelona: Editorial Ariel, 1988.

FERNÁNDEZ BULTÉ, Julio. Teoría del Estado. La Habana: Félix Varela, 2001.

FERNÁNDEZ RUIZ, Jorge. Poder legislativo. 2. ed. México: Porrúa-UNAM, 2004.

GARCÍA PELAYO, Manuel. Derecho constitucional comparado. Madrid: Alianza Editorial, 1984.

GUASTINI, Riccardo. Estudios de Teoría Constitucional. México: Fontamara, 2001.

HAURIOU, Maurice. Principio de Derecho público y constitucional. Madrid: Editorial Reus, 1927.

HEVIA DE LA JARA, Felipe. La iniciativa legislativa popular en América Latina. Revista Convergencia, Ciudad de México, vol. 17, n. 52, p. 155-185, ene./abr. 2010.

INTERNATIONAL INSTITUTE FOR DEMOCRACY AND ELECTORAL ASSISTANCE. Direct Democracy Handbook. Stockholm: International Institute for Democracy and Electoral Assistance, 2008.

JELLINEK, Georg. Reforma y mutación de la Constitución. Madrid: Centro de Estudios Constitucionales, 1991. 
KELSEN, Hans. Valor y esencia de la democracia. Oviedo: KRK ediciones, 2006.

LISSIDINI, Alicia. Democracia directa en América Latina. Buenos Aires: C2D, International IDEA, Escuela de Política y Gobierno UNSAM y Prometeo Libros, 2008.

LOEWENSTEIN, Karl. Political power and the governmental process. 2. ed. Chicago \& London: The University of Chicago Press, 1967.

LOEWENSTEIN, Karl. Teoría de la Constitución. 2. ed. Barcelona-Caracas-México: Ariel, 1979. MAIHOFER, Werner. Principios de una democracia en libertad. En: BENDA, Ernesto et. al (Org.). Manual de Derecho Constitucional. Madrid: Marcial Pons, 1996.

MENDES, Gilmar Ferreira; BRANCO, Paulo Gonet. Curso de Direito Constitucional. 9. ed. São Paulo: Saraiva, 2014.

MENDOZA DÍAZ, Juan. Derecho procesal. Parte general. La Habana: Félix Varela, 2015, p. 168. MORALES VITERI, Eduardo. Ecuador: mecanismos de democracia directa. Disponible en: <www. zora.uzh.ch/95761/1/C2D_WP20.pdf>. Acceso el 24.11.2017.

OTTERMAN, Steven. The European Citizens'Initiative: a Tool of Direct Democracy? En: ALTUNA, Asier; SUÁREZ, Mariluz (Org). New Voices in Euroculture. Groningen: Euroculture consortium. Disponible en: <www.rug.nl/research/portal/files/29253730/european.pdf>. Acceso el 13.06.2017.

PÉREZ ROYO, Javier. Curso de Derecho constitucional. 4. ed. Madrid: Marcial Pons, 1997.

QUIROGA LAVIÉ, Humberto. Derecho Constitucional Latinoamericano. México: UNAM, 1991.

SARTORI, Giovanni. Teoría de la democracia. El debate contemporáneo. Madrid: Alianza Editorial, 1995.

SCHMITT, Carl. Teoría de la Constitución. Madrid: Alianza Universidad Textos, 1992.

SILVA, José Alfonso da. Curso de Direito Constitucional positivo. 37. ed. São Paulo: Malheiros, 2013.

SOTO BARRIENTOS, Francisco. Mecanismos de participación ciudadana en el proceso legislativo. Los desafíos de su recepción en Chile. Oñati Socio-legal Series [online], Oñati, vol. 7, n. 5, p. 1-16. 2017. Disponible en <http://ssrn.com/abstract=3062784>. Acceso el 08.10.2017.

SUÁREZ ANTÓN, Orestes; WELP, Yanina. ¿Cambio o cumbia? Análisis de la iniciativa de agenda en América Latina. Revista Boliviana de Ciencias Políticas, [s.l.], vol. 1, n. 1, p. 79-107. 2017.

VANOSSI, Jorge Reynaldo. Estudios de Derecho Constitucional. México: UNAM, 2002. 